Paideusis

\title{
When You See Someone Clinging to a Rigid Paradigm, Do You Extend Your Hand, Do You Reach for a Hammer or Do You Walk Away?
}

\section{A Gentle Reader}

Volume 16, numéro 1, 2007

URI : https://id.erudit.org/iderudit/1072612ar

DOI : https://doi.org/10.7202/1072612ar

Aller au sommaire du numéro

Éditeur(s)

Canadian Philosophy of Education Society

ISSN

0838-4517 (imprimé)

1916-0348 (numérique)

Découvrir la revue

Citer ce document

A Gentle Reader (2007). When You See Someone Clinging to a Rigid Paradigm, Do You Extend Your Hand, Do You Reach for a Hammer or Do You Walk Away? Paideusis, 16(1), 79-79. https://doi.org/10.7202/1072612ar d'utilisation que vous pouvez consulter en ligne. 


\title{
When You See Someone Clinging to a Rigid Paradigm, Do You Extend Your Hand, Do You Reach for a Hammer or Do You Walk Away?
}

\author{
A GENTLE READER \\ In one world or another, somewhere in Canada
}

\begin{abstract}
This section invites readers to engage in dialogue by responding to content in previous issues of Paideusis or by initiating new discussions in the community. The Dialogue Section is meant to bring constructive and concise questions and concerns into a forum where students, scholars, and members of the interested public respectfully exchange views. Submissions to the Dialogue section will be selected and edited by members of the Editorial Board in order to ensure that the dialogue includes many voices and furthers thought.
\end{abstract}

Paideusis, on the peer review process

The title I have chosen above captures one of my more tempered thoughts after reading the dialogue piece in the previous issue. The quotation I have chosen above is taken from the Paideusis website and I cite it because I must ask how what appeared in this section in the previous issue was constructive or respectful (and if I wanted to take up the tenor of what appeared earlier, I would also ask how it initiated anything new or how it furthers thought...but that would be the first swing with a hammer and let's leave the hammer aside, shall we?).

Although in the dialogue piece (if I must call it that) of the previous issue Heesoon Bai was condemned because "it is not clear exactly what she intends," the intentions of the author whose name I will not repeat again and again and again are quite clear and clearly quite far from what belongs in a section called "Dialogue." Little wonder that philosophers of education have grave concerns about the future of philosophy of/in education. Evidently, there is good reason, if philosophy of/in education is as hostile, dismissive, and condescending as the dialogue piece in the previous issue would suggest. Things are worse than I thought.

I write this because I know all too well the rigid paradigms that have filled the world with cages, and truth be told, I sometimes wonder if it is wise to extend a hand to reach into a paradigmatic cage, because when I have done so in the past, I have met with clenched knuckles, glaring eyes, a sharp tongue. I am left not knowing what more to say other than, "Please yourself, hold on for your dear (and certain) life, but I refuse to live in that cage." When someone who is so resolutely clinging to a cage, if you extend your hand, is it not simply slapped away? Dialogue is difficult when it seems the only reasonable thing to do is walk away.

(C) Copyright 2007. The author assigns to Paideusis the right of first publication and educational and non-profit institutions a nonexclusive license to use this document for personal use and in courses of instruction provided that the document is used in full and this copyright statement is reproduced. Any other usage is probibited without the express permission of the author. 